\title{
Proposal of the Measurement Method of the Transmission Line Constants by Automatic Oscillograph Utilization
}

\author{
Yoshifumi OouraＭember（Kinkei System Corpration, VYU03013@nifty.ne.jp)
}

Keywords: earth return current, voltage-current of power system faults, four-terminal constants of three-phases, four-terminal eigenvector, transmission line eigenvector, transmission line eigenvalue mode

This article is a proposal of the methods to measure the transmission line constants with high precision using automatic oscillograph data.

Here, transmission line impedances and admittances assume it $Z_{33}[\Omega / \mathrm{km}]$ and $Y_{33}[\mathrm{~S} / \mathrm{km}]$, and, transmission line eigenvector assume it $P_{33}=$ eigenvecs $\left(Z_{33} Y_{33}\right)$ and $Q_{33}=$ eigenvecs $\left(Y_{33} Z_{33}\right)$. Then, as for the eigenvalue mode voltage-current of the power transmission line terminals, relations of Eq. (1) are concluded between both terminals.

$$
\begin{aligned}
& {\left[\begin{array}{l}
V_{m s_{3}} \\
\mathrm{I}_{\mathrm{ms}_{3}}
\end{array}\right]_{6}=\left[\begin{array}{ll}
A_{m_{33}} & B_{m_{33}} \\
C_{m_{33}} & D_{m_{33}}
\end{array}\right]_{66} \cdot\left[\begin{array}{l}
V_{m r_{3}} \\
\mathrm{I}_{\mathrm{m} r_{3}}
\end{array}\right]_{6}} \\
& V_{m s_{3}}=P_{33}^{-1} \cdot V_{s_{3}}, \quad V_{m r_{3}}=P_{33}^{-1} \cdot V_{r_{3}} \\
& \mathrm{I}_{\mathrm{m}_{3}}=Q_{33}^{-1} \cdot I_{s_{3}}, \quad \mathrm{I}_{\mathrm{m} r_{3}}=Q_{33}^{-1} \cdot I_{r_{3}} \\
& A_{m_{33}}=\left[\begin{array}{ccc}
\cosh \gamma_{\alpha} l & 0 & 0 \\
0 & \cosh \gamma_{\beta} l & 0 \\
0 & 0 & \cosh \gamma_{\gamma} l
\end{array}\right] \\
& B_{m_{33}}=\left[\begin{array}{ccc}
Z_{p \alpha} \sinh \gamma_{\alpha} l & 0 & 0 \\
0 & Z_{p \beta} \sinh \gamma_{\beta} l & 0 \\
0 & 0 & Z_{p \gamma} \sinh \gamma_{\gamma} l
\end{array}\right] \\
& C_{m_{33}}=\left[\begin{array}{ccc}
Y_{p \alpha} \sinh \gamma_{\alpha} l & 0 & 0 \\
0 & Y_{p \beta} \sinh \gamma_{\beta} l & 0 \\
0 & 0 & Y_{p \gamma} \sinh \gamma_{\gamma} l
\end{array}\right] \\
& D_{m_{33}}=A_{m_{33}} \text {, } \\
& Z_{m_{33}}=P_{33}^{-1} Z_{33} Q_{33}, \quad Y_{m_{33}}=Q_{33}^{-1} Y_{33} P_{33} \\
& \gamma_{k}=\sqrt{Z_{m_{k}} Y_{m_{k}}}, \quad Z_{p k}=1 / Y_{p k}=\sqrt{Z_{m_{k}} / Y_{m_{k}}} \\
& k=\alpha, \beta, \gamma
\end{aligned}
$$

Here, $V_{s_{3}}, I_{s_{3}}$ and $V_{r_{3}}, I_{r_{3}}$ are voltage-current of the transmission line terminals, and $1[\mathrm{~km}]$ is length of the transmission line.

$$
\begin{aligned}
& {\left[\begin{array}{l}
V_{s_{3}} \\
I_{s_{3}}
\end{array}\right]_{6}=\left[\begin{array}{l}
P_{33} V_{m_{3}} \\
Q_{33} I_{m_{3}}
\end{array}\right]_{6}=\left[\begin{array}{ll}
P_{33} A_{m_{33}} & P_{33} B_{m_{33}} \\
Q_{33} C_{m_{33}} & Q_{33} D_{m_{33}}
\end{array}\right]_{66}\left[\begin{array}{l}
P_{33}^{-1} V_{r_{3}} \\
Q_{33}^{-1} I_{r_{3}}
\end{array}\right]_{6}} \\
& =\left[\begin{array}{ll}
P_{33} A_{m_{33}} P_{33}^{-1} & P_{33} B_{m_{33}} Q_{33}^{-1} \\
Q_{33} C_{m_{33}} P_{33}^{-1} & Q_{33} D_{m_{33}} Q_{33}^{-1}
\end{array}\right]_{66}\left[\begin{array}{c}
V_{r_{3}} \\
I_{r_{3}}
\end{array}\right]_{6} \\
& \therefore \quad\left[\begin{array}{l}
V_{s_{3}} \\
I_{s_{3}}
\end{array}\right]_{6}=\left[\begin{array}{ll}
A_{33} & B_{33} \\
C_{33} & D_{33}
\end{array}\right]_{66}\left[\begin{array}{l}
V_{r_{3}} \\
I_{r_{3}}
\end{array}\right] \ldots \ldots \ldots \ldots \ldots \ldots \ldots \ldots \ldots \ldots \\
& A_{33}=P_{33} A_{m_{33}} P_{33}^{-1}, \quad B_{33}=P_{33} B_{m_{33}} Q_{33}^{-1} \\
& C_{33}=Q_{33} C_{m_{33}} P_{33}^{-1}, \quad D_{33}=Q_{33} D_{m_{33}} Q_{33}^{-1}
\end{aligned}
$$

Here, Eq. (2) shows relations of Eq. (3) becoming the key to transmission line constant measurements.

$$
\left.\begin{array}{l}
P_{33}=\text { eigenvecs }\left(Z_{33} Y_{33}\right)=\text { eigenvecs }\left(A_{3}\right) \\
Q_{33}=\operatorname{eigenvecs}\left(Y_{33} Z_{33}\right)=\operatorname{eigenvecs}\left(D_{33}\right)
\end{array}\right\}
$$

If actual survey of three phase four-terminal constants $\left(A_{33}, D_{33}\right.$, $B_{33}, C_{33}$ ) are possible, this Eq. (3) means that all constants (eigenvector matrixs $P_{33}, Q_{33}$ and other constants) actual survey of transmission line are enabled with relations of Eq. (1) and Eq. (2). And we can measure four-terminal constants $\left(A_{33}, D_{33}, B_{33}, C_{33}\right)$ of transmission line by next Eq. (4), if automatic oscillograph voltagecurrent data $\left(V_{s k 3}, I_{s k 3}\right.$ and $\left.V_{r k 3}, I_{r k 3}, k=1,2,3,4,5,6\right)$ of six independent system faults in transmission line terminals are provided.

$$
\begin{aligned}
{\left[\begin{array}{ll}
A_{33} & B_{33} \\
C_{33} & D_{33}
\end{array}\right]_{66}=} & {\left[\begin{array}{llllll}
V_{s 1_{3}} & V_{s 2_{3}} & V_{s 3_{3}} & V_{s 4_{3}} & V_{s 5_{3}} & V_{s 6_{3}} \\
I_{s 1_{3}} & I_{s 2_{3}} & I_{s 3_{3}} & I_{s 4_{3}} & I_{s 5_{3}} & I_{s 6_{3}}
\end{array}\right]_{66} } \\
& \times\left[\begin{array}{llllll}
V_{r 1_{3}} & V_{r 2_{3}} & V_{r 3_{3}} & V_{r 4_{3}} & V_{r 5_{3}} & V_{r 6_{3}} \\
I_{r 1_{3}} & I_{r 2_{3}} & I_{r 3_{3}} & I_{r 4_{3}} & I_{r 5_{3}} & I_{r 6_{3}}
\end{array}\right]_{66}^{-1}
\end{aligned}
$$

In other words, from Eqs. (1), (2) and (3), we can measure all transmission line constants by next.

$$
\left.\begin{array}{l}
k=\alpha, \beta, \gamma \\
\text { The diagonal elements of } P_{33}^{-1} A_{33} P_{33}=A_{m_{k}}=\cosh \gamma_{k} l \\
\text { The diagonal elements of } Q_{33}^{-1} D_{33} Q_{33}=D_{m_{k}}=\cosh \gamma_{k} l \\
\text { The diagonal elements of } P_{33}^{-1} B_{33} Q_{33}=B_{m_{k}}=Z_{p_{k}} \sinh \gamma_{k} l \\
\text { The diagonal elements of } Q_{33}^{-1} C_{33} P_{33}=C_{m_{k}}=Y_{p_{k}} \sinh \gamma_{k} l \\
\gamma_{k}=\sqrt{Z_{m_{k}} Y_{m_{k}}}=\frac{1}{l} \cosh ^{-1} A_{m_{k}}, \\
Z_{p_{k}}=\sqrt{Z_{m_{k}} / Y_{m_{k}}}=B_{m_{k}} / \sinh \gamma_{k} l \\
Z_{m_{k}}=\gamma_{k} \cdot Z_{p_{k}}, \quad Y_{m_{k}}=\gamma_{k} / Z_{p_{k}} \\
Z_{33}=P_{33} Z_{m_{33}} Q_{33}^{-1}, \quad Y_{33}=Q_{33} Y_{m_{33}} P_{33}^{-1}
\end{array}\right\}
$$

This actual survey technique was inspected by the system faults calculation by two-parallel line transmission line system of EMTP basically. And two-parallel line transmission line converted it by two-phase circuit theory.

The inspection values of the first circuit. ( $\rightarrow$ : element op.)

$$
\overrightarrow{\left(\mathrm{AmO}_{3} \cdot \mathrm{DmO}_{3}-\mathrm{Bm0}_{3} \cdot \mathrm{CmO}_{3}\right)}=\left(\begin{array}{c}
1.00000000000016 \\
1.00000000000062 \\
0.999999999998806
\end{array}\right)
$$

The inspection values of the second circuit.

$$
\overrightarrow{\left(\mathrm{Am}_{3} \cdot \mathrm{Dm}_{3}-\mathrm{Bm}_{3} \cdot \mathrm{Cm1}_{3}\right)}=\left(\begin{array}{c}
0.999999999957434 \\
0.99999999999352 \\
0.999999999972334
\end{array}\right)
$$

Relative errors of the first circuit mode surge imps.

$$
\overrightarrow{\left(\frac{|\mathrm{Zp} 03-\mathrm{Zp} 0|}{|\mathrm{Zp} 0|}\right)}=\left(\begin{array}{l}
0.000000000029144 \\
0.000000000039878 \\
0.000000000058746
\end{array}\right)
$$

Relative errors of the second circuit mode surge imps.

$$
\overrightarrow{\left(\frac{|\mathrm{Zp} 13-\mathrm{Zp} 1|}{|\mathrm{Zp} 1|}\right)}=\left(\begin{array}{l}
0.000000064757764 \\
0.000000981847929 \\
0.000005749727418
\end{array}\right)
$$

Relative errors of the one line three conductor imps.

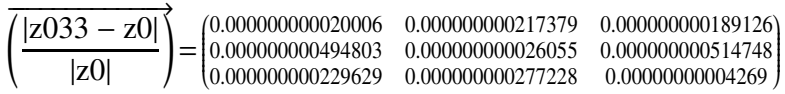




\title{
自動オシログラフ活用による送電線路定数実測手法の提案
}

\author{
正 員 大浦 好文* \\ Proposal of the Measurement Method of the Transmission Line Constants by \\ Automatic Oscillograph Utilization
}

Yoshifumi Ooura*, Member

\begin{abstract}
The author devised new method for measurement of the transmission line constants of high precision with the automatic oscillograph. This paper is proposal of new method for measurement of the transmission line constants. The author utilized that the inherent eigenvector matrixs of transmission line had an equal relation with four-terminal constants eigenvector matrixs of transmission line. And the author calculated four-terminal constants of transmission line from the data (voltage-current data of the automatic oscillograph) of six cases of transmission line system faults and devised the method for measurement for transmission line constants from analysis of the four-terminal constants of transmission line next. Furthermore, the author inspected this new method in the system fault simulations of the EMTP transmission line system model. It was shown that the result is the measurement method of high accuracy. From now on, the author advances the measurement of the transmission line constants from actual system faults data of the transmission line and its periphery with the cooperation power system companies.
\end{abstract}

キーワード : 大地帰路電流, 故障電圧電流, 三相 4 端子定数, 4 端子固有ベクトル, 送電線固有ベクトル, 送電線固有値モード Keywords: earth return current, voltage-current of power system faults, four-terminal constants of three-phases, four-terminal eigenvector, transmission line eigenvector, transmission line eigenvalue mode

\section{1. はじめに}

商用周波数域の架空送電線路定数は，すでに電気磁気理 論, 電氣回路論に基づく理論解析および数值解析手法が詳 細に解明・確立されており, EMTP や各種の線路定数計算 プログラムが広く普及, 活用されてきている。このため通 常の系統解析等には高精度線路定数の把握が可能であり殆 どの諸対策が的確に十分な精度で対応されてきている。こ の線路定数の中でただ一つ, 送電線自己インピーダンス（相 互インピーダンスや零相インピーダンスも同質）は，大地 帰路電流 (3 倍零相電流から架空地線電流を除いた分) の経 路とその地中電流分布に左右される性質がある。しかしな がら，計算では，無限直線状電線に平行・均質な大地の典型 的なモデル化(1) と代表の大地固有抵抗值で計算せざるを得 ない現実がある。一方，実際の架空送電線では送電ルート の左右・上下の蛇行や, 山脈地帯など大地固有抵抗值の大 きな変化等があり, 計算值と実際の值との差が不明である。 このため, 送電線自己インピーダンス・零相インピーダンス の影響を受け易い，例えば遮断器遮断容量限界を見極める

\footnotetext{
*(株) 近計システム

干 559-0031 大阪市住之江区南港東 8-2-61

Kinkei System Corporation

8-2-61, Nanko-Higashi, Suminoe-ku, Osaka 559-0031
}

地絡電流計算やインピーダンス型故障点標定装置の精度向 上等には実際の送電線自己インピーダンス・零相インピー ダンス把握検証が強く望まれる。この様な観点から, 著者 等は東京電力 (株) 在籍中'91〜'92 年にかけ $\mathrm{T}$ 社と $\mathrm{PCM}$ 電流作動リレーの送電線両端電圧電流同期計測機能を活用 した線路定数実測手法開発および実測の共同研究を組織的 に行った。この研究では, 集中定数 $\pi$ 回路近似を中心に多 くの検討を行ったが, 大きな大地帰路電流を伴う系統事故 時の自動記録機能がないため自己インピーダンスについて 十分な実測手法が得られず中断した。その後’00 年に, GSP 付きデジタル自動オシログラフの実用化が開始されたこと を契機に, 再び東京電力 (株) と（株）近計システム社と による線路定数実測手法の共同研究を行い, 固有值モード 法や瞬時值微分積分法などの多くの実測手法の検討を行っ てきたが，未知数の多いことと誤差の排除問題等から実用 的手法を見出すに至らなかった。

この様な長年の暗中模索の中で, 送電線を分布定数回路 化するために不可欠な三相 4 端子定数 A, B , C, D を対角 化する送電線固有ベクトル行列は, 逆にその 4 端子定数 $\mathrm{A}$, $\mathrm{D}$ 行列の固有ベクトル行列から求められるものであり, こ れによって全ての送電線線路定数の解析的な実測が可能で あることに気が付いた。

本論文は，そのアイデアによる実測手法を詳細に検討し 
ここに提案するものである。この提案は, 現在電力系統に 広く普及してきている GSP 付きデジタル自動オシログラ フの活用により，送電線の内部，外部の系統故障時におけ る両端子電圧電流記録 6 ケースのデジタル・データを用い, 当該送電線の線路定数を解析的に実測する手法と，模擬送 電系統シミュレーション数值検証により高精度実測が可能 であることを示すものである。

\section{2. 手法の理論的な意味合い}

\section{$\langle 2 \cdot 1\rangle$ 送電線両端子間の電圧電流と三相 4 端子定数}

平行 2 回線送電線，および 1 回線送電線は, 3 相分布定数 回路として扱うことができる。(平行 2 回線送電線は二相理 論により第一回路，第 2 回路の二つの 3 相分布定数回路に 置換可能）そして，送電線の送電端と受電端の間の電圧電 流の間には，送電線のインピーダンス行列 $\left(Z_{33}[\Omega / \mathrm{km}]\right)$ と アドミタンス行列 $\left(Y_{33}[\mathrm{~S} / \mathrm{km}]\right)$ ，および送電線固有べクト ル行列, $P_{33}=$ eigenvecs $\left(Z_{33} Y_{33}\right), Q_{33}=\operatorname{eigenvecs}\left(Y_{33} Z_{33}\right)$ により (2)，(1) 式の関係が成立している(2)。

$$
\begin{aligned}
& {\left[\begin{array}{l}
V_{m s_{3}} \\
\mathrm{I}_{\mathrm{ms}_{3}}
\end{array}\right]_{6}=\left[\begin{array}{ll}
A_{m_{33}} & B_{m_{33}} \\
C_{m_{33}} & D_{m_{33}}
\end{array}\right]_{66} \cdot\left[\begin{array}{l}
V_{m r_{3}} \\
\mathrm{I}_{\mathrm{m} r_{3}}
\end{array}\right]_{6}} \\
& V_{m s_{3}}=P_{33}^{-1} \cdot V_{s_{3}}, \quad V_{m r_{3}}=P_{33}^{-1} \cdot V_{r_{3}} \\
& \mathrm{I}_{\mathrm{m} s_{3}}=Q_{33}^{-1} \cdot I_{s_{3}}, \quad \mathrm{I}_{\mathrm{m} r_{3}}=Q_{33}^{-1} \cdot I_{r_{3}} \\
& A_{m_{33}}=\left[\begin{array}{ccc}
\cosh \gamma_{\alpha} l & 0 & 0 \\
0 & \cosh \gamma_{\beta} l & 0 \\
0 & 0 & \cosh \gamma_{\gamma} l
\end{array}\right] \\
& B_{m_{33}}=\left[\begin{array}{ccc}
Z_{p \alpha} \sinh \gamma_{\alpha} l & 0 & 0 \\
0 & Z_{p \beta} \sinh \gamma_{\beta} l & 0 \\
0 & 0 & Z_{p \gamma} \sinh \gamma_{\gamma} l
\end{array}\right] \\
& C_{m_{33}}=\left[\begin{array}{ccc}
Y_{p \alpha} \sinh \gamma_{\alpha} l & 0 & 0 \\
0 & Y_{p \beta} \sinh \gamma_{\beta} l & 0 \\
0 & 0 & Y_{p \gamma} \sinh \gamma_{\gamma} l
\end{array}\right] \\
& D_{m_{33}}=A_{m_{33}} \text {, } \\
& Z_{m_{33}}=P_{33}^{-1} Z_{33} Q_{33}, \quad Y_{m_{33}}=Q_{33}^{-1} Y_{33} P_{33} \\
& \gamma_{k}=\sqrt{Z_{m_{k}} Y_{m_{k}}}, \quad Z_{p k}=1 / Y_{p k}=\sqrt{Z_{m_{k}} / Y_{m_{k}}} \\
& k=\alpha, \beta, \gamma
\end{aligned}
$$

ここで, $V_{s_{3}}, I_{s_{3}}$ は送電端三相電圧電流ベクトル, $V_{r_{3}}, I_{r_{3}}$ は受電端三相電圧電流ベクトルであり, $l[\mathrm{~km}]$ は送電線亘 長である。この (1) 式から， $V_{s_{3}}, I_{s_{3}}$ と $V_{r_{3}}, I_{r_{3}}$ の関係を求 めると (2) 式が得られる(2)。

$$
\begin{aligned}
{\left[\begin{array}{c}
V_{s_{3}} \\
I_{s_{3}}
\end{array}\right]_{6} } & =\left[\begin{array}{l}
P_{33} V_{m s_{3}} \\
Q_{33} \mathrm{I}_{\mathrm{m} s_{3}}
\end{array}\right]_{6}=\left[\begin{array}{ll}
P_{33} A_{m_{33}} & P_{33} B_{m_{33}} \\
Q_{33} C_{m_{33}} & Q_{33} D_{m_{33}}
\end{array}\right]_{66}\left[\begin{array}{c}
P_{33}^{-1} V_{r_{3}} \\
Q_{33}^{-1} I_{r_{3}}
\end{array}\right]_{6} \\
& =\left[\begin{array}{ll}
P_{33} A_{m_{33}} P_{33}^{-1} & P_{33} B_{m_{33}} Q_{33}^{-1} \\
Q_{33} C_{m_{33}} P_{33}^{-1} & Q_{33} D_{m_{33}} Q_{33}^{-1}
\end{array}\right]_{66}\left[\begin{array}{c}
V_{r_{3}} \\
I_{r_{3}}
\end{array}\right]_{6}
\end{aligned}
$$

$$
\left.\begin{array}{l}
{\left[\begin{array}{l}
V_{s_{3}} \\
I_{s_{3}}
\end{array}\right]_{6}=\left[\begin{array}{ll}
A_{33} & B_{33} \\
C_{33} & D_{33}
\end{array}\right]_{66}\left[\begin{array}{l}
V_{r_{3}} \\
I_{r_{3}}
\end{array}\right]} \\
A_{33}=P_{33} A_{m_{33}} P_{33}^{-1}, \quad B_{33}=P_{33} B_{m_{33}} Q_{33}^{-1} \\
C_{33}=Q_{33} C_{m_{33}} P_{33}^{-1}, \quad D_{33}=Q_{33} D_{m_{33}} Q_{33}^{-1}
\end{array}\right\}
$$

上記 (1), (2) 式に示されている通り, 送電線固有ベクトル 行列 $P_{33}, Q_{33}$ は, 三相 4 端子定数行列 $A_{33}, B_{33}, C_{33}$, およ び $D_{33}$ を対角化するためのものである。これを逆に考えれ ば, $A_{33}, D_{33}$, の固有ベクトル行列を求めれば, 次の (3) 式 のとおり，それが送電線固有べクトル行列として用いるこ とができることであり, 線路定数の実測手法に応用できる。

$$
\left.\begin{array}{l}
P_{33}=\operatorname{eigenvecs}\left(Z_{33} Y_{33}\right)=\operatorname{eigenvecs}\left(A_{33}\right) \\
Q_{33}=\operatorname{eigenvecs}\left(Y_{33} Z_{33}\right)=\operatorname{eigenvecs}\left(D_{33}\right)
\end{array}\right\}
$$

すなわち, 三相 4 端子定数 $A_{33}, D_{33}, B_{33}$, および $C_{33}$ を 実測することができれば，送電線固有べクトル行列 $P_{33}$ お よび $Q_{33}$ をはじめ, すべての送電線路定数を，(1), (2) 式 の関係から解析的に求められることを意味している。

$\langle 2 \cdot 2\rangle$ 三相 4 端子定数行列 $A_{33}, C_{33}, B_{33}, D_{33}$ の実測 手法当該送電線多相再閉路遮断中や送電線外部故障中 などの 6 ケースの独立したパターンの送受電端三相電圧電 流， $V_{s k_{3}}, I_{s k_{3}}$, および $V_{r k_{3}}, I_{r k_{3}}(k=1,2,3,4,5,6)$ が得ら れれば, 次の (5) 式から, 三相 4 端子定数行列 $A_{33}, D_{33}$, $B_{33}$ ，および $C_{33}$ を実測することができる。

$$
\begin{aligned}
& {\left[\begin{array}{llllll}
V_{s 1_{3}} & V_{s 2_{3}} & V_{s 3_{3}} & V_{s 4_{3}} & V_{s 5_{3}} & V_{s 6_{3}} \\
I_{s 1_{3}} & I_{s 2_{3}} & I_{s 3_{3}} & I_{s 4_{3}} & I_{s 5_{3}} & I_{s 6_{3}}
\end{array}\right]_{66}} \\
& =\left[\begin{array}{ll}
A_{33} & B_{33} \\
c_{33} & D_{33}
\end{array}\right]_{66}\left[\begin{array}{llllll}
V_{r 1_{3}} & V_{r 2_{3}} & V_{r 3_{3}} & V_{r 4_{3}} & V_{r 5_{3}} & V_{r 6_{3}} \\
I_{r 1_{3}} & I_{r 2_{3}} & I_{r 3_{3}} & I_{r 4_{3}} & I_{r 5_{3}} & I_{r 6_{3}}
\end{array}\right]_{66}
\end{aligned}
$$

であるからよって

$$
\begin{aligned}
{\left[\begin{array}{ll}
A_{33} & B_{33} \\
C_{33} & D_{33}
\end{array}\right]_{66}=} & {\left[\begin{array}{llllll}
V_{s 1_{3}} & V_{s 2_{3}} & V_{s 3_{3}} & V_{s 4_{3}} & V_{s 5_{3}} & V_{s 6_{3}} \\
I_{s 1_{3}} & I_{s 2_{3}} & I_{s 3_{3}} & I_{s 4_{3}} & I_{s 5_{3}} & I_{s 6_{3}}
\end{array}\right]_{66} } \\
& \times\left[\begin{array}{llllll}
V_{r 1_{3}} & V_{r 2_{3}} & V_{r 3_{3}} & V_{r 4_{3}} & V_{r 5_{3}} & V_{r 6_{3}} \\
I_{r 1_{3}} & I_{r 2_{3}} & I_{r 3_{3}} & I_{r 4_{3}} & I_{r 5_{3}} & I_{r 6_{3}}
\end{array}\right]_{66}^{-1}
\end{aligned}
$$

$\langle 2 \cdot 3\rangle$ 三相 4 端子定数行列から線路定数の実測 上記 (1)，(2) 式，および (3) 式から，直ちに

$$
\left.\begin{array}{l}
k=\alpha, \beta, \gamma \text { として, } \\
P_{33}^{-1} A_{33} P_{33} \text { の対角要素 }=A_{m_{k}}=\cosh \gamma_{k} l \\
Q_{33}^{-1} D_{33} Q_{33} \text { の対角要素 }=D_{m_{k}}=\cosh \gamma_{k} l \\
P_{33}^{-1} B_{33} Q_{33} \text { の対角要素 }=B_{m_{k}}=Z_{p_{k}} \sinh \gamma_{k} l \\
Q_{33}^{-1} C_{33} P_{33} \text { の対角要素 }=C_{m_{k}}=Y_{p_{k}} \sinh \gamma_{k} l
\end{array}\right\}
$$

ないし, $A_{33}$ の固有值 $=A_{m_{k}}, D_{33}, B_{33}, C_{33}$ も同様 
したがって, (6) 式(2) から送電線固有值モードにおける伝 播定数 $\gamma_{k}$, サージインピーダンス $Z_{p_{k}}$, インピーダンス $Z_{m_{k}}$ およびアドミタンス $Y_{m_{k}}$ を次の (7) 式により実測できる。

$$
\left.\begin{array}{l}
k=\alpha, \beta, \gamma \text { として, } \\
\gamma_{k}=\sqrt{Z_{m_{k}} Y_{m_{k}}}=\frac{1}{l} \cosh ^{-1} A_{m_{k}} \\
Z_{p_{k}}=\sqrt{Z_{m_{k}} / Y_{m_{k}}}=\sqrt{B_{m_{k}} / C_{m_{k}}} \\
Z_{m_{k}}=\gamma_{k} \cdot Z_{p_{k}}, \quad Y_{m_{k}}=\gamma_{k} / Z_{p_{k}}
\end{array}\right\}
$$

上記 (7) 式 (2) のモード各定数を得て, (3) 式の送電線固有 ベクトル行列を用い, 送電線の相別インピーダンス行列お よびアドミタンス行列が，(8) 式により実測可能となる。

$$
\left[\begin{array}{ccc}
Z_{m_{\alpha}} & 0 & 0 \\
0 & Z_{m_{\beta}} & 0 \\
0 & 0 & Z_{m_{\gamma}}
\end{array}\right]=Z_{m_{33}}, \quad\left[\begin{array}{ccc}
Y_{m_{\alpha}} & 0 & 0 \\
0 & Y_{m_{\beta}} & 0 \\
0 & 0 & Y_{m_{\gamma}}
\end{array}\right]=Y_{m_{33}}
$$

として

$$
Z_{33}=P_{33} Z_{m_{33}} Q_{33}^{-1}, \quad Y_{33}=Q_{33} Y_{m_{33}} P_{33}^{-1}
$$

\section{3. 具体的実測手法}

〈3・1〉 送電線端子電圧電流データの収集 現在普及 している自動オシログラフ ${ }^{(3)}$ は, 送電線端子電圧電流を 16 ビット，64９6 サンプリング/1 サイクルでデジタル化し， 端子間データは GPS 利用によるサンプリング自動同期した 上で自動記録している。この瞬時值電圧電流データは, バ ンドパス・デジタル・フィルター演算で基本波を抽出した 上，実効值演算と位相差角演算により高精度の基本波成分 の実効値ベクトル量に加工して用いる。ここで，故障時電 圧電流に基本波の $2.5 \sim 3.5$ 倍程度の過渡的振動成分の少な い系統では，1 サイクル DFT 演算でも実効值ベクトル量に 十分な精度が得られている(3)。また, 必要に応じ, VT, CT について，その回路と計測類の負担インピーダンス等を調 査し，誤差補正を行う。また，端子間データの演算照合に よるサンプリング同期ズレ補正を行う。この様にして得る 送電線両端子電圧電流・実効值ベクトル量データをパター ンの独立した 6 ケース収集する。

例えば，今回の検証シミュレーションに用いた，

(i ) 1 号線停止中の常時潮流データ

(ii) 1 号線 b, c 相再閉路遮断中でアーク消弧後デー夕

(iii) 1,2 号線 c, c’ 相再閉路遮断中でアーク消弧後デー夕

(iv) 1, 2 号線 a, c' 相再閉路遮断中でアーク消弧後デー夕

(v) 送電端外部 b 相地絡事故中デー夕

(vi) 受電端外部 $\mathrm{a}, \mathrm{b}$ 相地絡事故中デー夕

の様に, 電圧電流パターンが比例関係からほど遠く独立状 態にある6ケースを収集する。そして，6ケース中 4 ケー ス以上は大きな大地帰路電流を含み, 平行 2 回線併用送電 線では，いずれかの相が，1，2号線ループ・オフ状態にあ るケースが必要である。 $\langle\mathbf{3} \cdot 2\rangle$ 相配列の扱いと二相回路扱い 電圧電流は, 実 際の $\mathrm{a}$ 相, b 相, c 相, で扱うより, 鉄塔構造に合わせた, 上線- $\mathrm{h}$, 中線- $\mathrm{m}$, 下線-1, の区別で扱う。ここでは, 1 号 線-j，2 号線-k の添え字で区別する。

Fig. 1 の導体配列の例では相電圧電流を (9) 式とする。 また, 2 回線の電圧電流を Fig. 2 の通り二相理論により 第 1 回路と第 2 回路の二つの三相回路の電圧電流に変換す る。1 号線, 2 号線の電圧電流から第 1 回路および第 2 回 路に変換した電圧電流は, (9) 式から, 次の (10) 式となる。

$$
\begin{aligned}
& \text { 送電端電圧電流 } \\
& V_{s j_{3}}=\left[\begin{array}{c}
V_{s j_{h}} \\
V_{s j_{m}} \\
V_{s j_{l}}
\end{array}\right]=\left[\begin{array}{c}
V_{s j_{b}} \\
V_{s j_{c}} \\
V_{s j_{a}}
\end{array}\right], \quad V_{s k_{3}}=\left[\begin{array}{c}
V_{s k_{h}} \\
V_{s k_{m}} \\
V_{s k_{l}}
\end{array}\right]=\left[\begin{array}{c}
V_{s k_{a}} \\
V_{s k_{c}} \\
V_{s k_{b}}
\end{array}\right] \\
& I_{s j_{3}}=\left[\begin{array}{c}
I_{s j_{h}} \\
I_{s j_{m}} \\
I_{s j_{l}}
\end{array}\right]=\left[\begin{array}{c}
I_{s j_{b}} \\
I_{s j_{c}} \\
I_{s j_{a}}
\end{array}\right], \quad I_{s k_{3}}=\left[\begin{array}{c}
I_{s k_{h}} \\
I_{s k_{m}} \\
I_{s k_{l}}
\end{array}\right]=\left[\begin{array}{c}
I_{s k_{a}} \\
I_{s k_{c}} \\
I_{s k_{b}}
\end{array}\right]
\end{aligned}
$$

受電端電圧電流

$$
\begin{gathered}
V_{r j_{3}}=\left[\begin{array}{c}
V_{r j_{h}} \\
V_{r j_{m}} \\
V_{r j_{l}}
\end{array}\right]=\left[\begin{array}{c}
V_{r j_{b}} \\
V_{r j_{c}} \\
V_{r j_{a}}
\end{array}\right], \quad V_{r k_{3}}=\left[\begin{array}{c}
V_{r k_{h}} \\
V_{r k_{m}} \\
V_{r k_{l}}
\end{array}\right]=\left[\begin{array}{c}
V_{r k_{a}} \\
V_{r k_{c}} \\
V_{r k_{b}}
\end{array}\right] \\
I_{r j_{3}}=\left[\begin{array}{c}
I_{r j_{h}} \\
I_{r j_{m}} \\
I_{r j_{l}}
\end{array}\right]=\left[\begin{array}{c}
I_{r j_{b}} \\
I_{r j_{c}} \\
I_{r j_{a}}
\end{array}\right], \quad I_{r k_{3}}=\left[\begin{array}{c}
I_{r k_{h}} \\
I_{r k_{m}} \\
I_{r k_{l}}
\end{array}\right]=\left[\begin{array}{c}
I_{r k_{a}} \\
I_{r k_{c}} \\
I_{r k_{b}}
\end{array}\right]
\end{gathered}
$$

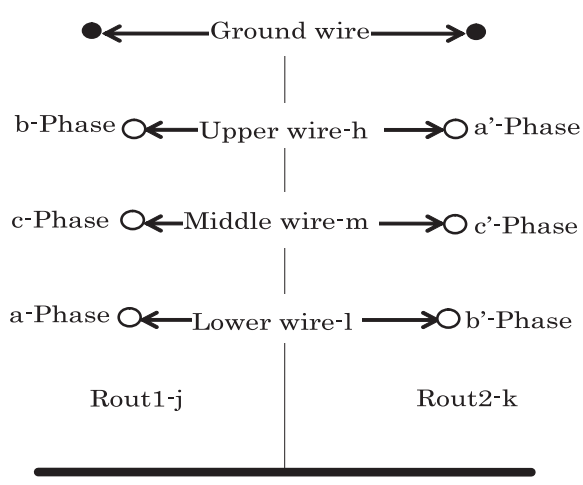

Fig. 1. Sample arrangement of conductors.

2 Rout circuit

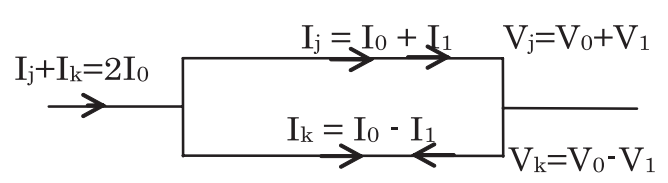

First circuit

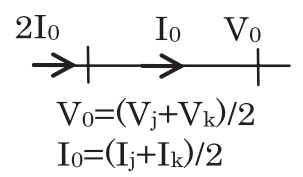

Second circuit

Fig. 2. Voltages and currents of two phase theory. 


$$
\left.\begin{array}{lc}
\text { 送電端 第 } 1 \text { 回路 } & \text { 第 } 2 \text { 回路 } \\
V_{s 0_{3}}=\frac{1}{2}\left(V_{s j_{3}}+V_{s k_{3}}\right), & V_{s 1_{3}}=\frac{1}{2}\left(V_{s j_{3}}-V_{s k_{3}}\right) \\
I_{s 0_{3}}=\frac{1}{2}\left(I_{s j_{3}}+I_{s k_{3}}\right), & I_{s 1_{3}}=\frac{1}{2}\left(I_{s j_{3}}-I_{s k_{3}}\right) \\
\text { 受電端 } \quad \text { 第 } 1 \text { 回路 } & \text { 第 } 2 \text { 回路 } \\
V_{r 0_{3}}=\frac{1}{2}\left(V_{r j_{3}}+V_{r k_{3}}\right), & V_{r 1_{3}}=\frac{1}{2}\left(V_{r j_{3}}-V_{r k_{3}}\right) \\
I_{r 0_{3}}=\frac{1}{2}\left(I_{r j_{3}}+I_{r k_{3}}\right), & I_{r 1_{3}}=\frac{1}{2}\left(I_{r j_{3}}-I_{r k_{3}}\right)
\end{array}\right\}
$$

また， 1 号線，2 号線それぞれの回線内インピーダンス 行列, アドミタンス行列を $Z_{33}[\Omega / \mathrm{km}], Y_{33}[\mathrm{~S} / \mathrm{km}]$ とし, 1 号線と 2 号線の間の回線間相互インピーダンス行列，アド ミタンス行列を $z_{33}[\Omega / \mathrm{km}], y_{33}[\mathrm{~S} / \mathrm{km}]$ として, 行列各要素 を電線上線から順に Fig. 1 鉄塔配列に合わせた配列の (11) 式の通りとする。

$$
\left.\begin{array}{rl}
Z_{33}=\left[\begin{array}{lll}
Z_{h h} & Z_{h m} & Z_{h l} \\
Z_{m h} & Z_{m m} & Z_{m l} \\
Z_{l h} & Z_{l m} & Z_{l l}
\end{array}\right], & z_{33}=\left[\begin{array}{lll}
z_{h h} & z_{h m} & z_{h l} \\
z_{m h} & z_{m m} & z_{m l} \\
z_{l h} & z_{l m} & z_{l l}
\end{array}\right] \\
Y_{33}=\left[\begin{array}{lll}
Y_{h h} & Y_{h m} & Y_{h l} \\
Y_{m h} & Y_{m m} & Y_{m l} \\
Y_{l h} & Y_{l m} & Y_{l l}
\end{array}\right], & y_{33}=\left[\begin{array}{lll}
y_{h h} & y_{h m} & y_{h l} \\
y_{m h} & y_{m m} & y_{m l} \\
y_{l h} & y_{l m} & y_{l l}
\end{array}\right]
\end{array}\right\}
$$

送電端から， $x[\mathrm{~km}]$ における電圧電流では,

$$
\left.\begin{array}{ll}
\frac{d V_{j_{3}}}{d x}=-Z_{33} I_{j_{3}}-z_{33} I_{k_{3}}, & \frac{d I_{j_{3}}}{d x}=-Y_{33} V_{j_{3}}-y_{33} V_{k_{3}} \\
\frac{d V_{k_{3}}}{d x}=-Z_{33} I_{k_{3}}-z_{33} I_{j_{3}}, & \frac{d I_{k_{3}}}{d x}=-Y_{33} V_{k_{3}}-y_{33} V_{j_{3}}
\end{array}\right\}
$$

よって，(10) 式の関係から,

$$
\left.\begin{array}{rl}
\frac{d V_{0_{3}}}{d x}=-Z_{0_{33}} I_{0_{3}}, \quad \frac{d I_{0_{3}}}{d x}=-Y_{0_{33}} V_{0_{3}} \\
\frac{d V_{1_{3}}}{d x}=-Z_{1_{33}} I_{1_{3}}, \quad \frac{d I_{1_{3}}}{d x}=-Y_{1_{33}} V_{1_{3}} \\
\text { ただし, } Z_{0_{33}}=Z_{33}+z_{33}, \quad Z_{1_{33}}=Z_{33}-z_{33} \\
Y_{0_{33}}=Y_{33}+y_{33}, \quad Y_{1_{33}}=Y_{33}-y_{33}
\end{array}\right\}
$$

として, 第 1 回路と第 2 回路の二つの独立した三相電圧電 流の方程式を得る。(13) 式から，さらに

$$
\left.\begin{array}{ll}
\frac{d^{2} V_{0_{3}}}{d x^{2}}=Z_{0_{33}} Y_{0_{33}} V_{0_{3}}, & \frac{d^{2} I_{0_{3}}}{d x^{2}}=Y_{0_{33}} Z_{0_{33}} I_{0_{3}} \\
\frac{d^{2} V_{1_{3}}}{d x^{2}}=Z_{1_{33}} Y_{1_{33}} V_{1_{3}}, & \frac{d^{2} I_{0_{3}}}{d x^{2}}=Y_{1_{33}} Z_{1_{33}} I_{1_{3}}
\end{array}\right\}
$$

ここで，(13) 式と (14) 式を次の固有ベクトル行列を用い変 換すると，(17) 式の固有值モードの方程式を得る。
$P_{0_{33}}=$ eigenvecs $\left(Z_{0_{33}} Y_{0_{33}}\right), \quad Q_{0_{33}}=$ eigenvecs $\left(Y_{0_{33}} Z_{0_{33}}\right)$

$P_{1_{33}}=$ eigenvecs $\left.\left(Z_{1_{33}} Y_{1_{33}}\right), \quad Q_{1_{33}}=\operatorname{eigenvecs}\left(Y_{1_{33}} Z_{1_{33}}\right)\right\}$

$$
\left.\begin{array}{l}
V_{m 0_{3}}=P_{0_{33}}^{-1} V_{0_{3}}, \quad \mathrm{I}_{\mathrm{m}_{3}}=Q_{0_{33}}^{-1} I_{0_{3}} \\
V_{m 1_{3}}=P_{1_{33}}^{-1} V_{1_{3}}, \quad \mathrm{I}_{\mathrm{m} 1_{3}}=Q_{1_{33}}^{-1} I_{1_{3}} \\
Z_{m 0_{33}}=P_{0_{3}}^{-1} Z_{0_{33}} Q_{0_{33}}, \quad Y_{m 0_{33}}=Q_{0_{33}}^{-1} Y_{0_{33}} P_{0_{33}} \\
Z_{m 1_{33}}=P_{1_{33}}^{-1} Z_{1_{33}} Q_{1_{33}}, \quad Y_{m 1_{33}}=Q_{1_{33}}^{-1} Y_{1_{33}} P_{1_{33}}
\end{array}\right\}
$$

$\frac{d V_{m 0_{3}}}{d x}=-Z_{m 0_{33}} \mathrm{I}_{\mathrm{m} 0_{3}}, \quad \frac{d \mathrm{I}_{\mathrm{m} 0_{3}}}{d x}=-Y_{m 0_{33}} V_{m 0_{3}}$

$\frac{d V_{m 1_{3}}}{d x}=-Z_{m 1_{33}} \mathrm{I}_{m 1_{3}}, \quad \frac{d I_{1_{3}}}{d x}=-Y_{m 1_{33}} V_{m 1_{3}}$

$$
\left.\begin{array}{ll}
\frac{d^{2} V_{m 0_{3}}}{d x^{2}}=Z_{m 0_{33}} Y_{m 0_{33}} V_{m 0_{3}}, & \frac{d^{2} \mathrm{I}_{\mathrm{m} 0_{3}}}{d x^{2}}=Y_{m 0_{33}} Z_{m 0_{33}} \mathrm{I}_{\mathrm{m} 0_{3}} \\
\frac{d^{2} V_{m 1_{3}}}{d x^{2}}=Z_{m 1_{33}} Y_{m 1_{33}} V_{m 1_{3}}, & \frac{d^{2} \mathrm{I}_{\mathrm{m} 1_{3}}}{d x^{2}}=Y_{m 1_{33}} Z_{m 1_{33}} \mathrm{I}_{\mathrm{m}_{3}}
\end{array}\right\}
$$

(17) 式中の行列は, 全て対角化行列であり解が得られる。 ここで, $x=0$ で電圧電流を送電端の電圧電流, $x=l[\mathrm{~km}]$ で受電端電圧電流として求めると, (1) 式で示した送電端電 圧と受電端電圧電流関係と同様の関係式が第 1 回路（添え 字 0 を付加して）および第 2 回路（添え字 1 を付加して） それぞれで成立する。

したがって，送受電端の相別電圧電流の関係も (2) 式と 同様に第 1 回路および第 2 回路それぞれで成立する。

それはまた, 2 回線分の送受電端電圧電流 6 ケースから 第 1 回路拉よび第 2 回路の電圧電流 6 ケースが得られ, (5) 式と同様の演算により第 1 回路抢よび第 2 回路それぞれの 三相 4 端子定数が実測できる。この三相 4 端子定数の実測 值から，(6) 式，および (7) 式と同様の演算により, 次の第 1 回路㧍よびだ 2 回路それぞれについて送電線モード定数 を実測することができる。

第 1 回路 $\gamma_{0_{\alpha}}, \gamma_{0_{\beta}}, \gamma_{0_{\gamma}}, Z_{p 0_{\alpha}}, Z_{p 0_{\beta}}, Z_{p 0_{\gamma}}$

$$
\left.Z_{0 m_{33}}=\left[\begin{array}{ccc}
Z_{0 m_{\alpha}} & 0 & 0 \\
0 & Z_{0 m_{\beta}} & 0 \\
0 & 0 & Z_{0 m_{\gamma}}
\end{array}\right], \quad Y_{0 m_{33}}=\left[\begin{array}{ccc}
Y_{0 m_{\alpha}} & 0 & 0 \\
0 & Y_{0 m_{\beta}} & 0 \\
0 & 0 & Y_{0 m_{\gamma}}
\end{array}\right]\right\}
$$

第 2 回路 $\gamma_{1_{\alpha}}, \gamma_{1_{\beta}}, \gamma_{1_{\gamma}}, Z_{p 1_{\alpha}}, Z_{p 1_{\beta}}, Z_{p 1_{\gamma}}$

$$
\left.Z_{1 m_{33}}=\left[\begin{array}{ccc}
Z_{1 m_{\alpha}} & 0 & 0 \\
0 & Z_{1 m_{\beta}} & 0 \\
0 & 0 & Z_{1 m_{\gamma}}
\end{array}\right], \quad Y_{1 m_{33}}=\left[\begin{array}{ccc}
Y_{1 m_{\alpha}} & 0 & 0 \\
0 & Y_{1 m_{\beta}} & 0 \\
0 & 0 & Y_{1 m_{\gamma}}
\end{array}\right]\right\}
$$

この (18)，(19) 式が実測できることにより，(8)式と同様 にして, 第 1 回路および第 2 回路の相別インピーダンス行列 およびアドミタンス行列を次の (20) 式により実測できる。 


$$
\left.\begin{array}{ll}
Z_{0_{33}}=P_{0_{33}} Z_{m 0_{33}} Q_{0_{33}}^{-1}, & Y_{0_{33}}=Q_{0_{33}} Y_{m 0_{33}} P_{0_{33}}^{-1} \\
Z_{1_{33}}=P_{1_{33}} Z_{m 1_{33}} Q_{1_{33}}^{-1}, & Y_{1_{33}}=Q_{1_{33}} Y_{m 1_{33}} P_{1_{33}}^{-1}
\end{array}\right\}
$$

この (20) 式から, 我々が多く用いる 1 号線, 2 号線それ ぞれの回線内インピーダンス行列とアドミタンス行列，な らびに 1 号線と 2 号線の間の回線間相互インピーダンス行 列，アドミタンス行列を，(13)式の関係により実測できる。

$$
\left.\begin{array}{rl}
Z_{33} & =\left[\begin{array}{lll}
Z_{h h} & Z_{h m} & Z_{h l} \\
Z_{m h} & Z_{m m} & Z_{m l} \\
Z_{l h} & Z_{l m} & Z_{l l}
\end{array}\right]=\frac{1}{2}\left(Z_{0_{33}}+Z_{1_{33}}\right) \\
z_{33} & =\left[\begin{array}{lll}
z_{h h} & z_{h m} & z_{h l} \\
z_{m h} & z_{m m} & z_{m l} \\
z_{l h} & z_{l m} & z_{l l}
\end{array}\right]=\frac{1}{2}\left(Z_{0_{33}}-Z_{1_{33}}\right) \\
Y_{33} & =\left[\begin{array}{lll}
Y_{h h} & Y_{h m} & Y_{h l} \\
Y_{m h} & Y_{m m} & Y_{m l} \\
Y_{l h} & Y_{l m} & Y_{l l}
\end{array}\right]=\frac{1}{2}\left(Y_{0_{33}}+Y_{1_{33}}\right) \\
y_{33} & =\left[\begin{array}{lll}
y_{h h} & y_{h m} & y_{h l} \\
y_{m h} & y_{m m} & y_{m l} \\
y_{l h} & y_{l m} & y_{l l}
\end{array}\right]=\frac{1}{2}\left(Y_{0_{33}}-Y_{1_{33}}\right)
\end{array}\right\}
$$

\section{$\langle\mathbf{3} \cdot \mathbf{3}\rangle$ 定数算出上の留意事項}

（1） 実測に際しては中々大地帰路電流の大きな系統故 障ケースのデータが得られ難い。現段階の実測過程でも線 路定数実測精度の要である送電線固有べクトル行列 $P, Q$ については，実測した 4 端子定数の $A, D$ から (3) 式の関係 を利用して求める， $P, Q$ のみでなく $\mathrm{Q}$ から， $P=\left(Q^{T}\right)^{-1}$ の関係を用いた方が数值計算上，精度向上する傾向も見ら れており，この扱いは今後の課題である。

（2）モード 4 端子定数を求める際においても，4 端子 定数の固有值から求めるより, 上記 $P, Q$ から求める方が 大きく精度向上する傾向が見られている。

（3）（7）式の通り，モード・サージインピーダンス $Z_{P}$ は，モード・インピーダンス $Z_{m}$ ，およびモード・アドミタ ンス $Y_{m}$, さらには線路インピーダンス $Z$ およびアドミタ ンス $Y$ 算出過程で必ず必要になる值であるが，その $Z_{P}$ 算 出の際には, 数值極性扱いに注意を要する $\sinh \gamma l$ の計算を 避け (7) 式により求めることとしている。

\section{4. シミュレーションによる検証結果}

〈4・1〉 実測手法と 6 ケース独立性および数值解析の検 証平行 2 回線鉄塔分布定数送電線ならびにその両側 連係系統を EMTPにより構成し〈3・1〉節で示した常時 潮流や当該送電線の内外区間における故障時の電圧電流を シミュレーションした。その電圧電流について, Mathsoft Engineering \& Education Inc. の Mathcad11 ソフトを用い て数值解析計算を行い標記の検証を行った。模擬分布定数 送電線は, Fig. 1 に示した相配列を用い, その送電線と連
Transmission line: 2 Parallel line

Power line wire: LN-ACSR940 $\times 8$ Conductors Ground wire: LN-OPGW480

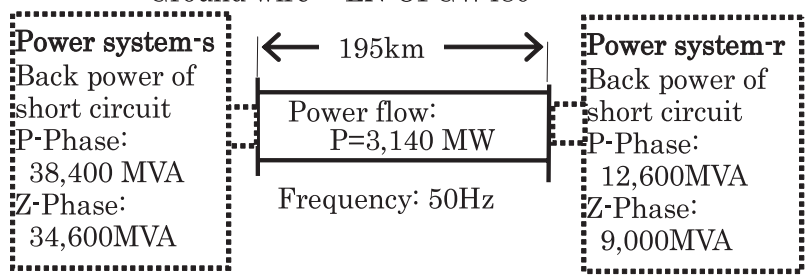

Fig. 3. Transmission line model and power system model.

係系統モデルの概要を Fig. 3 に示す。

EMTPによるこの模擬系統において，〈3・1〉節で述べた 6 ケース, 1 回線停止中常時潮流と, 送電線内外故障時の送 電端の電圧 $[\mathrm{kV}]$, 電流 $[\mathrm{kA}]$ シミュレーション值を示す。 送電端（表示は，小数点以下 3 林まで）

1 号線 (行: Va, Vb, Vc, Ia, Ib, Ic 順, 列 : ケース 1, 2, 3, 4, 5, 6 順)

$\left(\begin{array}{cccccc}-9.97-13.24 \mathrm{j} & 305.82+93.36 \mathrm{j} & 316.4+95.42 \mathrm{j} & -48.54-14.2 \mathrm{j} & 312.49+123.67 \mathrm{j} & 250.25+83.98 \mathrm{j} \\ 14.52+19.46 \mathrm{j} & 53.29+36.6 \mathrm{j} & -65.91-305.9 \mathrm{j} & -56.82-319.26 \mathrm{j} & -16.83-4.33 \mathrm{j} & -31.36-282.93 \mathrm{j} \\ -2.65+7.14 \mathrm{j} & 75.21+37.41 \mathrm{j} & 88.66-61.28 \mathrm{j} & -251.33+203.88 \mathrm{j} & -223.76+257.75 \mathrm{j} & -229.7+217.03 \mathrm{j} \\ 0+0 \mathrm{j} & 2.08+0.41 \mathrm{j} & 2.03+0.9 \mathrm{j} & 0+0 \mathrm{j} & 1.91+0.32 \mathrm{j} & 3.07-3.56 \mathrm{j} \\ -0-0 \mathrm{j} & -0-0 \mathrm{j} & -1.44-1.58 \mathrm{j} & -1.25-3.45 \mathrm{j} & 1.43-2.65 \mathrm{j} & -2.99+0.75 \mathrm{j} \\ -0+0 \mathrm{j} & -0+0 \mathrm{j} & -0+0 \mathrm{j} & -1.86+4.35 \mathrm{j} & -2.24+2.22 \mathrm{j} & -1.14+2.91 \mathrm{j}\end{array}\right)$

2 号線 (行: Va, Vb, Vc, Ia, Ib, Ic 順, 列: ケース 1 , 2, 3, 4, 5, 6 順)

$\left(\begin{array}{cccccc}303.7+102.23 \mathrm{j} & 305.82+93.36 \mathrm{j} & 316.4+95.42 \mathrm{j} & 305.59+116.16 \mathrm{j} & 312.49+123.67 \mathrm{j} & 250.25+83.98 \mathrm{j} \\ -64.97-317.7 \mathrm{j} & -65.1-315.35 \mathrm{j} & -65.91-305.9 \mathrm{j} & -56.82-319.26 \mathrm{j} & -16.83-4.33 \mathrm{j} & -31.36-282.93 \mathrm{j} \\ -239.75+214.7 \mathrm{j} & -239.77+215.93 \mathrm{j} & 86.33-63.38 \mathrm{j} & 29.07-51.14 \mathrm{j} & -223.76+257.75 \mathrm{j} & -229.7+217.03 \mathrm{j} \\ 3.27-0.01 \mathrm{j} & 2.35-0.1 \mathrm{j} & 2.03+0.93 \mathrm{j} & 4.28+0.94 \mathrm{j} & 1.88+0.33 \mathrm{j} & 3.12-3.55 \mathrm{j} \\ -1.17-3.03 \mathrm{j} & -1.52-3.08 \mathrm{j} & -1.4-1.57 \mathrm{j} & -1.34-2.8 \mathrm{j} & 1.46-2.63 \mathrm{j} & -2.97+0.69 \mathrm{j} \\ -2.01+2.93 \mathrm{j} & -2.22+2.9 \mathrm{j} & -0+0 \mathrm{j} & -0+0 \mathrm{j} & -2.24+2.23 \mathrm{j} & -1.12+2.17 \mathrm{j}\end{array}\right)$

受電端

1 号線 (行: Va, Vb, Vc, Ia, Ib, Ic 順, 列: ケース 1, 2, 3, 4, 5, 6 順)

$\left(\begin{array}{cccccc}-18.19-2.67 \mathrm{j} & 312.87-37.54 \mathrm{j} & 289.83-39.11 \mathrm{j} & -51+33.43 \mathrm{j} & 308.08-42.76 \mathrm{j} & 47.89+30.5 \mathrm{j} \\ 21.13+5.05 \mathrm{j} & 60.85-0.87 \mathrm{j} & -203.06-261.15 \mathrm{j} & -226.92-225.76 \mathrm{j} & -158.83-143.72 \mathrm{j} & -13.46-35.1 \mathrm{j} \\ -0.67+7.29 \mathrm{j} & 80.49-3.55 \mathrm{j} & 19.94-96.81 \mathrm{j} & -70.22+321.43 \mathrm{j} & -138.43+264.29 \mathrm{j} & -159.13+360.32 \mathrm{j} \\ -0+0 \mathrm{j} & 2.11+0.18 \mathrm{j} & 2.1+0.67 \mathrm{j} & -0+0 \mathrm{j} & 1.89+0.04 \mathrm{j} & 3.06-3.71 \mathrm{j} \\ 0+0 \mathrm{j} & 0+0 \mathrm{j} & -1.64-1.43 \mathrm{j} & -1.49-3.35 \mathrm{j} & 1.31-2.59 \mathrm{j} & -3.19+0.74 \mathrm{j} \\ 0-0 \mathrm{j} & 0-0 \mathrm{j} & 0-0 \mathrm{j} & -1.6+4.45 \mathrm{j} & -2.05+2.4 \mathrm{j} & -0.91+2.35 \mathrm{j}\end{array}\right)$

2 号線 (行: Va, Vb, Vc, Ia, Ib, Ic 順, 列：ケース 1 , 2, 3, 4, 5, 6 順)

$\left(\begin{array}{cccccc}314.25-63.5 \mathrm{j} & 312.87-37.54 \mathrm{j} & 289.83-39.11 \mathrm{j} & 306.42-99.97 \mathrm{j} & 308.08-42.76 \mathrm{j} & 47.89+30.5 \mathrm{j} \\ -205.92-230.77 \mathrm{j} & -206.39-234.73 \mathrm{j} & -203.06-261.15 \mathrm{j} & -226.92-225.76 \mathrm{j} & -158.83-143.72 \mathrm{j} & -13.46-35.1 \mathrm{j} \\ -103.68+296.45 \mathrm{j} & -104.28+295.42 \mathrm{j} & 17.24-98.29 \mathrm{j} & -12.3-54.97 \mathrm{j} & -138.43+264.29 \mathrm{j} & -159.13+360.32 \mathrm{j} \\ 3.26-0.29 \mathrm{j} & 2.34-0.36 \mathrm{j} & 2.11+0.69 \mathrm{j} & 4.32+0.68 \mathrm{j} & 1.86+0.05 \mathrm{j} & 3.12-3.71 \mathrm{j} \\ -1.42-2.94 \mathrm{j} & -1.78-2.96 \mathrm{j} & -1.59-1.42 \mathrm{j} & -1.54-2.69 \mathrm{j} & 1.35-2.56 \mathrm{j} & -3.16+0.68 \mathrm{j} \\ -1.77+3.09 \mathrm{j} & -1.98+3.09 \mathrm{j} & 0-0 \mathrm{j} & 0-0 \mathrm{j} & -2.04+2.41 \mathrm{j} & -0.89+2.34 \mathrm{j}\end{array}\right)$

この送受電端 6 ケース・デー夕を自動オシロ記録デー夕 と見立てて, 相配列を上線 $\mathrm{h}$, 中線 $\mathrm{m}$, 下線 1 , の順とし, 第 1 回路, 第 2 回路に変換の上, 三相 4 端子定数を求めた (注，(5) 式参照）結果は以下の值である。

第 1 回路（表示は, 小数点以下 7 桁まで）

$\mathrm{A}_{33}=\left(\begin{array}{ccc}0.9673737+0.0030997 \mathrm{j} & -0.0069916+0.0019588 \mathrm{j} & -0.0096383+0.0030275 \mathrm{j} \\ -0.0105666+0.0027818 \mathrm{j} & 0.9722243+0.0023935 \mathrm{j} & -0.010108+0.0030391 \mathrm{j} \\ -0.009907+0.0029035 \mathrm{j} & -0.0069227+0.0020521 \mathrm{j} & 0.9682784+0.003488 \mathrm{j}\end{array}\right)$ 
$B 0_{33}=\left(\begin{array}{ccc}15.8691956+131.8389263 \mathrm{j} & 15.3680064+83.4660816 \mathrm{j} & 15.7051995+70.9337221 \mathrm{j} \\ 15.3680064+83.4660816 \mathrm{j} & 16.5495373+130.5512154 \mathrm{j} & 16.0712486+82.2265719 \mathrm{j} \\ 15.7051995+70.9337221 \mathrm{j} & 16.0712486+82.2265719 \mathrm{j} & 17.278922+129.1671215 \mathrm{j}\end{array}\right)$

$\mathrm{CO}_{33}=\left(\begin{array}{lll}-0.0000003+0.0006678 \mathrm{j} & -0.0000002-0.0002218 \mathrm{j} & -0.0000003-0.0000775 \mathrm{j} \\ -0.0000002-0.0002218 \mathrm{j} & -0.0000002+0.0006985 \mathrm{j} & -0.0000002-0.0002193 \mathrm{j}\end{array}\right)$

$\left(\begin{array}{lll}-0.0000003-0.0000775 \mathrm{j} & -0.0000002-0.0002193 \mathrm{j} & -0.0000004+0.0006644 \mathrm{j}\end{array}\right)$

$\mathrm{D}_{33}=\left(\begin{array}{ccc}0.9673737+0.0030997 \mathrm{j} & -0.0105666+0.0027818 \mathrm{j} & -0.009907+0.0029035 \mathrm{j} \\ -0.0069916+0.0019588 \mathrm{j} & 0.9722243+0.0023935 \mathrm{j} & -0.0069227+0.0020521 \mathrm{j} \\ -0.0096383+0.0030275 \mathrm{j} & -0.010108+0.0030391 \mathrm{j} & 0.9682784+0.003488 \mathrm{j}\end{array}\right)$

第 2 回路

$\begin{aligned} \mathrm{A} 1_{33} & =\left(\begin{array}{ccc}0.9783806+0.0003611 \mathrm{j} & -0.0002024-0.0000447 \mathrm{j} & -0.0001838-0.0000067 \mathrm{j} \\ -0.0003075-0.0000443 \mathrm{j} & 0.9789382+0.0003575 \mathrm{j} & -0.0001927-0.0000452 \mathrm{j} \\ -0.0002209-0.0000068 \mathrm{j} & -0.0001577-0.0000458 \mathrm{j} & 0.9788022+0.0003522 \mathrm{j}\end{array}\right) \\ \mathrm{B} 1_{33} & =\left(\begin{array}{ccc}0.8427303+51.7862638 \mathrm{j} & 0.0111328+8.008644 \mathrm{j} & 0.0121284+3.2425846 \mathrm{j} \\ 0.0111328+8.008644 \mathrm{j} & 0.8458812+52.1761544 \mathrm{j} & 0.0143725+8.2904011 \mathrm{j} \\ 0.0121284+3.2425846 \mathrm{j} & 0.0143725+8.2904011 \mathrm{j} & 0.8494071+52.5515762 \mathrm{j}\end{array}\right) \\ \mathrm{C} 1_{33} & =\left(\begin{array}{ccc}-0.0000001+0.0008452 \mathrm{j} & 0-0.0001141 \mathrm{j} & 0-0.0000259 \mathrm{j} \\ 0-0.0001141 \mathrm{j} & -0.0000001+0.0008352 \mathrm{j} & 0-0.0001189 \mathrm{j} \\ 0-0.0000259 \mathrm{j} & 0-0.0001189 \mathrm{j} & -0.0000001+0.0008185 \mathrm{j}\end{array}\right)\end{aligned}$ $\mathrm{D} 1_{33}=\left(\begin{array}{ccc}0.9783806+0.0003611 \mathrm{j} & -0.0003075-0.0000443 \mathrm{j} & -0.0002209-0.0000068 \mathrm{j} \\ -0.0002024-0.0000447 \mathrm{j} & 0.9789382+0.0003575 \mathrm{j} & -0.0001577-0.0000458 \mathrm{j} \\ -0.0001838-0.0000067 \mathrm{j} & -0.0001927-0.0000452 \mathrm{j} & 0.9788022+0.0003522 \mathrm{j}\end{array}\right)$

このシミュレーション実測の三相 4 端子定数の $A_{33}$ と $D_{33}$ から, 送電線固有ベクトル行列の一例を求める（注, (3) 式 参照）と次の通り。

第 1 回路（表示は, 小数点以下 7 桁まで）

$\begin{aligned} \mathrm{PO}_{33} & =\left(\begin{array}{ccc}0.586349 & 0.7085568 & -0.2569226-0.0022609 \mathrm{j} \\ 0.5712466-0.0070836 \mathrm{j} & -0.0546043-0.0069932 \mathrm{j} & 0.9029504 \\ 0.5741897-0.0113232 \mathrm{j} & -0.7031008-0.0237881 \mathrm{j} & -0.3444252+0.0061176 \mathrm{j}\end{array}\right) \\ \mathrm{Q}_{33} & =\left(\begin{array}{ccc}0.6541964 & 0.7255936 & -0.3706011-0.0025334 \mathrm{j} \\ 0.4245164-0.0119267 \mathrm{j} & -0.0552152+0.0007573 \mathrm{j} & 0.819557 \\ 0.625358-0.0244539 \mathrm{j} & -0.6857412-0.0149576 \mathrm{j} & -0.4369875+0.0040802 \mathrm{j}\end{array}\right)\end{aligned}$

第 2 回路

$\begin{aligned} \mathrm{P1}_{33} & =\left(\begin{array}{ccc}0.8071318 & -0.4504728-0.0508765 \mathrm{j} & -0.1587715-0.0328503 \mathrm{j} \\ 0.4324306+0.0537679 \mathrm{j} & 0.3165471+0.0020976 \mathrm{j} & 0.9004239 \\ 0.3971929+0.0298142 \mathrm{j} & 0.8332343 & -0.4014653-0.04213 \mathrm{j}\end{array}\right) \\ \mathrm{Q} 1_{33} & =\left(\begin{array}{ccc}0.8780222 & -0.5350946-0.0518991 \mathrm{j} & -0.2379355-0.0254492 \mathrm{j} \\ 0.312269+0.0617868 \mathrm{j} & 0.2644939+0.0087857 \mathrm{j} & 0.8581967 \\ 0.3562106+0.0293522 \mathrm{j} & 0.800591 & -0.453112-0.030447 \mathrm{j}\end{array}\right)\end{aligned}$

この送電線固有ベクトル行列で, 上記三相 4 端子定数を 固有值モードに変換したモード 4 端子定数（対角要素）の 值とその 4 端子定数の検証值は，次の通りとなる。

第 1 回路

$$
\begin{aligned}
& \mathrm{Am}_{3}=\left(\begin{array}{c}
0.951205913604539+0.008243290524355 \mathrm{j} \\
0.977597637651811+0.000337196557537 \mathrm{j} \\
0.97907289762068+0.000400773743889 \mathrm{j}
\end{array}\right) \\
& \mathrm{Bm}_{3}=\left(\begin{array}{c}
50.2379847432469+282.208904521427 \mathrm{j} \\
1.2618949104717+59.5399390371929 \mathrm{j} \\
0.798394090402367+44.4721983737043 \mathrm{j}
\end{array}\right) \\
& \mathrm{Cm}_{3}=\left(\begin{array}{c}
-0.000004391119053+0.000336823747468 \mathrm{j} \\
-0.000004695177178+0.000743988799077 \mathrm{j} \\
0.000000926991508+0.000931304576385 \mathrm{j}
\end{array}\right)
\end{aligned}
$$

$$
\mathrm{Dm0}_{3}=\left(\begin{array}{c}
0.951205913605402+0.00824329052509 \mathrm{j} \\
0.977597637649934+0.000337196557343 \mathrm{j} \\
0.979072897620944+0.000400773743108 \mathrm{j}
\end{array}\right)
$$

第 1 回路の検証值 ( $\rightarrow$ は, 同位置要素の間の演算を示す)

$$
\overrightarrow{\left(\mathrm{Am}_{3} \cdot \mathrm{Dm0}_{3}-\mathrm{Bm0}_{3} \cdot \mathrm{Cm0}_{3}\right)}=\left(\begin{array}{c}
1.00000000000016 \\
1.00000000000062 \\
0.999999999998806
\end{array}\right)
$$

第 2 回路

$$
\begin{aligned}
& \mathrm{Am}_{3}=\left(\begin{array}{c}
0.978184947428789+0.000313586045831 \mathrm{j} \\
0.978861378020821+0.000351573376911 \mathrm{j} \\
0.979074573164126+0.00040564091223 \mathrm{j}
\end{array}\right) \\
& \mathrm{Bm}_{3}=\left(\begin{array}{c}
0.195414422067005+60.8654310622134 \mathrm{j} \\
0.92745601901738+51.0414506887778 \mathrm{j} \\
1.30272519636141+43.4402759454382 \mathrm{j}
\end{array}\right) \\
& \mathrm{Cm}_{3}=\left(\begin{array}{c}
0.000007803021589+0.000709036821157 \mathrm{j} \\
-0.000001406321356+0.000819514754324 \mathrm{j} \\
-0.000010295197143+0.000953026472044 \mathrm{j}
\end{array}\right) \\
& \mathrm{Dm}_{3}=\left(\begin{array}{l}
0.978184947410006+0.000313586069149 \mathrm{j} \\
0.978861378014485+0.000351573366187 \mathrm{j} \\
0.979074573121993+0.000405640885769 \mathrm{j}
\end{array}\right)
\end{aligned}
$$

第 2 回路の検証値

$$
\overrightarrow{\left(\mathrm{Am}_{3} \cdot \mathrm{Dml}_{3}-\mathrm{Bml}_{3} \cdot \mathrm{Cm}_{3}\right)}=\left(\begin{array}{c}
0.999999999957434 \\
0.99999999999352 \\
0.999999999972334
\end{array}\right)
$$

この 4 端子定数検証值から, 実測手法, 6 ケースの独立 性, および数值解析の妥当性が確認できたものと考えられ る。(参考, モード 4 端子定数は, 固有ベクトル行列を用い ず, 三相 4 端子定数の固有值として直接求めることも可能, しかしその計算法では検証值が 6 桁程度低下)

$\langle\mathbf{4} \cdot \mathbf{2}\rangle$ 実測手法とその数值解析誤差の検証 $\langle 4 \cdot 1\rangle$ 節 で実測算出した固有值ベクトル行列とモード 4 端子定数に より，全ての線路定数の実測が可能である。

この実測值精度を検証（このシミュレーションでは, 実 効值入力部までの検証は別) するため, 次の理想線路定数 計測值との比較検証を行った。

（1）模擬平行 2 回線送電線路定数の理想的な計測 測定用三相の 3 回完全独立電圧行列 $E_{33}$ を, 次式の電圧 行列により，

$$
E_{33}=E \cdot\left[\begin{array}{ccc}
1 & 1 & 0 \\
1 & -1 / 2 & 1 \\
1 & -1 / 2 & -1
\end{array}\right] \quad[\mathrm{V}]
$$

Fig. 4 の通り印加し, 送電端電流および受電端電圧電流を Fig. 4 の通り計測する。この計測值から (22) 式により, 模 擬送電線三相 4 端子定数を計測し, それをこの模擬送電線 線路定数の真值とした。 

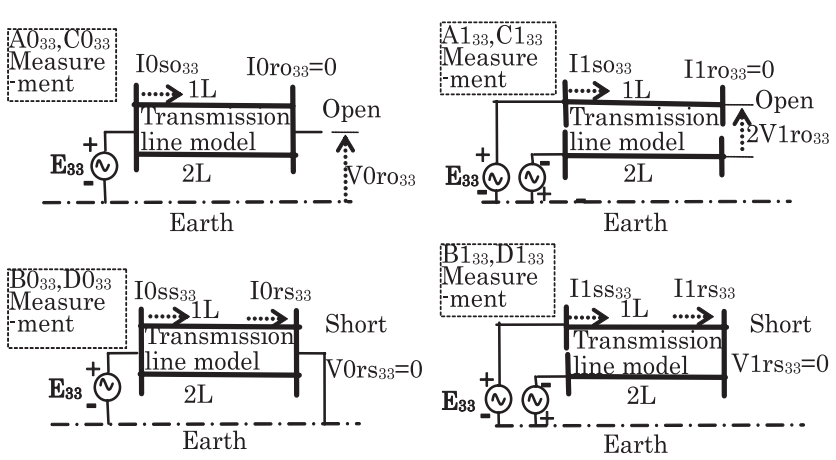

Fig. 4. Ideal measurement of the four-terminal constants of the transmission line.

$$
\left.\begin{array}{l}
E_{33}=A_{0_{33}} V_{0 r o_{33}}, \quad \therefore A_{0_{33}}=E_{33} \cdot V_{0 r o_{33}}^{-1} \\
I_{00_{33}}=C_{0_{33}} V_{0 r o_{33}}, \quad \therefore C_{0_{33}}=I_{0 s o_{33}} \cdot V_{0 r o_{33}}^{-1} \\
E_{33}=B_{0_{33}} I_{0 r s_{33}}, \quad \therefore B_{0_{33}}=E_{33} \cdot I_{0 r s_{33}}^{-1} \\
I_{0 s s_{33}}=D_{0_{33}} I_{0 r s_{33}}, \quad \therefore D_{0_{33}}=I_{0 s s_{33}} \cdot I_{0 r s_{33}}^{-1} \\
E_{33}=A_{1_{33}} V_{0 r o_{33}}, \quad \therefore A_{1_{33}}=E_{33} \cdot V_{1 r o_{33}}^{-1} \\
I_{1 s o_{33}=C_{1_{33}} V_{1 r o_{33}},} \therefore C_{1_{33}}=I_{1 s o_{33}} \cdot V_{1 r o_{33}}^{-1} \\
E_{33}=B_{1_{33} I_{1 r s_{33}},} \quad \therefore B_{1_{33}}=E_{33} \cdot I_{1 r s_{33}}^{-1} \\
I_{1 s s_{33}}=D_{1_{33}} I_{0 r s_{33}}, \quad \therefore D_{1_{33}}=I_{1 s s_{33}} \cdot I_{1 r s_{33}}^{-1}
\end{array}\right\}
$$$$
\text { ……....... (22) }
$$

模擬送電線の理想計測による主な定数は次の通り。 第 1 回路 4 端子定数（表示は，小数点以下 7 桁まで）
$\mathrm{A} 0=\left(\begin{array}{ccc}0.9673737+0.0030997 \mathrm{j} & -0.0069916+0.0019588 \mathrm{j} & -0.0096383+0.0030275 \mathrm{j} \\ -0.0105666+0.0027818 \mathrm{j} & 0.9722243+0.0023935 \mathrm{j} & -0.010108+0.0030391 \mathrm{j} \\ -0.009907+0.0029035 \mathrm{j} & -0.0069227+0.0020521 \mathrm{j} & 0.9682784+0.003488 \mathrm{j}\end{array}\right)$
$\left(\begin{array}{lll}15.8691956+131.8389263 \mathrm{j} & 15.3680064+83.4660816 \mathrm{j} & 15.7051995+70.9337221 \mathrm{j}\end{array}\right)$
$\mathrm{B} 0=\left(\begin{array}{ccc}15.3680064+83.4660816 \mathrm{j} & 16.5495373+130.5512154 \mathrm{j} & 16.0712486+82.2265719 \mathrm{j}\end{array}\right)$ $\left(\begin{array}{lll}15.7051995+70.9337221 \mathrm{j} & 16.0712486+82.2265719 \mathrm{j} & 17.278922+129.1671215 \mathrm{j}\end{array}\right)$
$\mathrm{C} 0=\left(\begin{array}{lll}-0.0000003+0.0006678 \mathrm{j} & -0.0000002-0.0002218 \mathrm{j} & -0.0000003-0.0000775 \mathrm{j} \\ -0.0000002-0.0002218 \mathrm{j} & -0.0000002+0.0006985 \mathrm{j} & -0.0000002-0.0002193 \mathrm{j} \\ -0.000003-0.0000775 \mathrm{j} & -0.0000002-0.0002193 \mathrm{j} & -0.0000004+0.0006644 \mathrm{j}\end{array}\right)$ $\left(\begin{array}{lll}-0.0000003-0.0000775 \mathrm{j} & -0.0000002-0.0002193 \mathrm{j} & -0.0000004+0.0006644 \mathrm{j}\end{array}\right)$
$\mathrm{D} 0=\left(\begin{array}{ccc}0.9673737+0.0030997 \mathrm{j} & -0.0105666+0.0027818 \mathrm{j} & -0.009907+0.0029035 \mathrm{j} \\ -0.0069916+0.0019588 \mathrm{j} & 0.9722243+0.0023935 \mathrm{j} & -0.0069227+0.0020521 \mathrm{j} \\ -0.0096383+0.0030275 \mathrm{j} & -0.010108+0.0030391 \mathrm{j} & 0.9682784+0.003488 \mathrm{j}\end{array}\right)$

第 2 回路 4 端子定数（表示は，小数点以下 7 桁まで）

$\mathrm{A} 1=\left(\begin{array}{ccc}0.9783806+0.0003611 \mathrm{j} & -0.0002024-0.0000447 \mathrm{j} & -0.0001838-0.0000067 \mathrm{j} \\ -0.0003075-0.0000443 \mathrm{j} & 0.9789382+0.0003575 \mathrm{j} & -0.0001927-0.0000452 \mathrm{j} \\ -0.0002209-0.0000068 \mathrm{j} & -0.0001577-0.0000458 \mathrm{j} & 0.9788022+0.0003522 \mathrm{j}\end{array}\right)$
$\mathrm{B} 1=\left(\begin{array}{ccc}0.8427303+51.7862634 \mathrm{j} & 0.0111328+8.0086437 \mathrm{j} & 0.0121284+3.2425846 \mathrm{j} \\ 0.0111328+8.0086437 \mathrm{j} & 0.8458811+52.1761541 \mathrm{j} & 0.0143725+8.2904011 \mathrm{j} \\ 0.0121284+3.2425843 \mathrm{j} & 0.0143725+8.2904007 \mathrm{j} & 0.8494071+52.5515762 \mathrm{j}\end{array}\right)$

$\mathrm{C} 1=\left(\begin{array}{ccc}-0.0000001+0.0008452 \mathrm{j} & 0-0.0001141 \mathrm{j} & 0-0.0000259 \mathrm{j} \\ 0-0.0001141 \mathrm{j} & -0.0000001+0.0008352 \mathrm{j} & 0-0.0001189 \mathrm{j}\end{array}\right.$ $0-0.0000259 \mathrm{j} \quad 0-0.0001189 \mathrm{j} \quad-0.0000001+0.0008185 \mathrm{j})$

$\mathrm{D} 1=\left(\begin{array}{ccc}0.9783806+0.0003611 \mathrm{j} & -0.0003075-0.0000443 \mathrm{j} & -0.0002209-0.0000068 \mathrm{j} \\ -0.0002024-0.0000447 \mathrm{j} & 0.9789382+0.0003575 \mathrm{j} & -0.0001577-0.0000458 \mathrm{j} \\ -0.0001838-0.0000067 \mathrm{j} & -0.0001927-0.0000452 \mathrm{j} & 0.9788022+0.0003522 \mathrm{j}\end{array}\right)$

第 1 回路固有ベクトル行列 (表示は, 小数点以下 7 桁まで)

$\mathrm{P} 0=\left(\begin{array}{ccc}0.586349 & 0.7085568 & -0.2569226-0.0022609 \mathrm{j} \\ 0.5712466-0.0070836 \mathrm{j} & -0.0546043-0.0069932 \mathrm{j} & 0.9029504 \\ 0.5741897-0.0113232 \mathrm{j} & -0.7031008-0.0237881 \mathrm{j} & -0.3444252+0.0061176 \mathrm{j}\end{array}\right)$
$\mathrm{Q} 0=\left(\begin{array}{ccc}0.6541964 & 0.7255936 & -0.3706011-0.0025334 \mathrm{j} \\ 0.4245164-0.0119267 \mathrm{j} & -0.0552152+0.0007573 \mathrm{j} & 0.819557 \\ 0.625358-0.0244539 \mathrm{j} & -0.6857412-0.0149576 \mathrm{j} & -0.4369875+0.0040801 \mathrm{j}\end{array}\right)$

第 2 回路固有ベクトル行列 (表示は, 小数点以下 7 桁まで)

$\mathrm{P} 1=\left(\begin{array}{ccc}0.8071299 & -0.4504667-0.0508762 \mathrm{j} & -0.1587511-0.0328533 \mathrm{j} \\ 0.4324319+0.0537674 \mathrm{j} & 0.3165563+0.0020973 \mathrm{j} & 0.9004059 \\ 0.3971953+0.0298141 \mathrm{j} & 0.8332341 & -0.4015151-0.0421153 \mathrm{j}\end{array}\right)$

$\mathrm{Q} 1=\left(\begin{array}{ccc}0.8780222 & -0.5350947-0.0518991 \mathrm{j} & -0.2379356-0.0254492 \mathrm{j} \\ 0.312269+0.0617868 \mathrm{j} & 0.2644939+0.0087857 \mathrm{j} & 0.8581967 \\ 0.3562105+0.0293522 \mathrm{j} & 0.800591 & -0.4531118-0.0304472 \mathrm{j}\end{array}\right)$

自回線インピーダンス（表示は, 小数点以下 7 桁まで）

$$
Z=\left(\begin{array}{ccc}
0.0443069+0.477046 \mathrm{j} & 0.0408309+0.238716 \mathrm{j} & 0.0417228+0.1939635 \mathrm{j} \\
0.0408304+0.2387138 \mathrm{j} & 0.046073+0.4745196 \mathrm{j} & 0.0426773+0.2361742 \mathrm{j} \\
0.041723+0.1939651 \mathrm{j} & 0.0426753+0.2361675 \mathrm{j} & 0.0480093+0.4719654 \mathrm{j}
\end{array}\right)
$$

回線間相互インピーダンス (表示は, 小数点以下 7 桁まで)

$$
\mathrm{Z}=\left(\begin{array}{ccc}
0.0399172+0.2092551 \mathrm{j} & 0.040771+0.1972774 \mathrm{j} & 0.0416592+0.1771771 \mathrm{j} \\
0.0407715+0.1972796 \mathrm{j} & 0.0416697+0.2047611 \mathrm{j} & 0.0426013+0.1932886 \mathrm{j} \\
0.0416589+0.1771754 \mathrm{j} & 0.0426033+0.1932953 \mathrm{j} & 0.0435851+0.2002491 \mathrm{j}
\end{array}\right)
$$

自回線アドミタンス実測值（表示 $\mu \mathrm{S}$ ，小数点以下 7 桁 まで)

$\mathrm{Y}=\left(\begin{array}{ccc}0.0003689+3.9156396 \mathrm{j} & 0.0001223-0.8658357 \mathrm{j} & 0.000243-0.2643958 \mathrm{j} \\ 0.0001313-0.8657882 \mathrm{j} & 0.0002466+3.9662143 \mathrm{j} & 0.0001199-0.8718699 \mathrm{j} \\ 0.0002337-0.2644444 \mathrm{j} & 0.000151-0.871755 \mathrm{j} & 0.0003397+3.8371579 \mathrm{j}\end{array}\right)$

回線間相互インピーダンス（表示 $\mu \mathrm{S}$ ，小数点以下 7 桁 まで)

$\mathrm{y}=\left(\begin{array}{ccc}0.0002447-0.4548453 \mathrm{j} & 0.0001701-0.2762448 \mathrm{j} & 0.0002403-0.1306074 \mathrm{j} \\ 0.0001611-0.2762923 \mathrm{j} & 0.0000893-0.3519562 \mathrm{j} & 0.000157-0.2575462 \mathrm{j} \\ 0.0002496-0.1305588 \mathrm{j} & 0.0001259-0.2576612 \mathrm{j} & 0.0002316-0.3948335 \mathrm{j}\end{array}\right)$

（2）線路定数の主な実測值と誤差の検証結果

(1) モード相・伝播定数 $[/ \mathrm{km}]$

第 1 回路実測值

$$
\gamma 03=\left(\begin{array}{l}
0.000136675419821+0.001615923793499 \mathrm{j} \\
0.000008224100178+0.001088733465883 \mathrm{j} \\
0.000010109446762+0.001052162830715 \mathrm{j}
\end{array}\right)
$$

理想計測との比較誤差率 ( $\rightarrow$ は, 行列要素間の演算)

$$
\overrightarrow{\left(\frac{|\gamma 03-\gamma 0|}{|\gamma 0|}\right)}=\left(\begin{array}{c}
0.000000000002939 \\
0.00000000002585 \\
0.000000000024899
\end{array}\right)
$$

\section{第 2 回路実測值}

$$
\gamma 13=\left(\begin{array}{l}
0.000007749387135+0.001074311675365 \mathrm{j} \\
0.000008824465116+0.001057473756695 \mathrm{j} \\
0.000010232614083+0.001052121738606 \mathrm{j}
\end{array}\right)
$$

理想計測との比較誤差率 ( $\rightarrow$ は, 行列要素間の演算 $)$

$$
\overrightarrow{\left(\frac{|\gamma 13-\gamma 1|}{|\gamma 1|}\right)}=\left(\begin{array}{l}
0.000000349385667 \\
0.000000077019961 \\
0.000000117070366
\end{array}\right)
$$


(2) モード・サージインピーダンス $[\Omega]$

第 1 回路実測值

$$
\mathrm{Zp0}_{3}=\left(\begin{array}{c}
918.346375685636-87.1391845990423 \mathrm{j} \\
282.8944118921-3.89027705226969 \mathrm{j} \\
218.533340107356-1.85270005143572 \mathrm{j}
\end{array}\right)
$$

理想計測との比較誤差率（（は，行列要素間の演算）

$$
\overrightarrow{\left(\frac{|\mathrm{Zp} 03-\mathrm{Zp} 0|}{|\mathrm{Zp} 0|}\right)}=\left(\begin{array}{l}
0.000000000029144 \\
0.000000000039878 \\
0.000000000058746
\end{array}\right)
$$

第 2 回路実測值

$$
\mathrm{Zp}_{3}=\left(\begin{array}{c}
292.978417525229+1.14175288746255 \mathrm{j} \\
249.572755003489-2.48141950217021 \mathrm{j} \\
213.49536020666-4.35399897514409 \mathrm{j}
\end{array}\right)
$$

理想計測との比較誤差率 ( $\rightarrow$ は, 行列要素間の演算 $)$

$$
\overrightarrow{\left(\frac{|\mathrm{Zp} 13-\mathrm{Zp} 1|}{|\mathrm{Zp} 1|}\right)}=\left(\begin{array}{l}
0.000000064757764 \\
0.000000981847929 \\
0.000005749727418
\end{array}\right)
$$

(3) モード・インピーダンス $[\Omega / \mathrm{km}]$

第 1 回路実測值

$$
\mathrm{Zm}_{3}=\left(\begin{array}{c}
0.266325658177689+1.47206797450632 \mathrm{j} \\
0.006562026801626+0.307964619510038 \mathrm{j} \\
0.004158593298131+0.229913927960416 \mathrm{j}
\end{array}\right)
$$

理想計測との比較誤差率 ( $\rightarrow$ は, 行列要素間の演算 $)$

$$
\overrightarrow{\left(\frac{|\mathrm{Zm} 03-\mathrm{Zm} 0|}{|\mathrm{Zm} 0|}\right)}=\left(\begin{array}{l}
0.000000000026667 \\
0.000000000018984 \\
0.000000000065965
\end{array}\right)
$$

第 2 回路実測值

$$
\mathrm{Zm}_{3}=\left(\begin{array}{c}
0.00104380472218+0.314758982462403 \mathrm{j} \\
0.004826382073367+0.263894741602475 \mathrm{j} \\
0.006765552601056+0.224578556773758 \mathrm{j}
\end{array}\right)
$$

理想計測との比較誤差率 ( $\rightarrow$ は, 行列要素間の演算)

$$
\overrightarrow{\left(\frac{|\mathrm{Zm} 13-\mathrm{Zm} 1|}{|\mathrm{Zm} 1|}\right)}=\left(\begin{array}{l}
0.000000342329657 \\
0.000001056734269 \\
0.000005693141012
\end{array}\right)
$$

(4) モード・アドミタンス $[\mathrm{S} / \mathrm{km}]$

第 1 回路実測值

$$
\mathrm{Ym}_{3}=\left(\begin{array}{c}
-0.000000017973848+0.00000175789616 \mathrm{j} \\
-0.000000023848305+0.000003848222671 \mathrm{j} \\
0.000000005441953+0.000004814702015 \mathrm{j}
\end{array}\right)
$$

理想計測との比較誤差率（（は，行列要素間の演算）

$$
\overrightarrow{\left(\frac{|\mathrm{Ym} 03-\mathrm{Ym} 0|}{|\mathrm{Ym} 0|}\right)}=\left(\begin{array}{l}
0.000000000031701 \\
0.000000000064471 \\
0.000000000061569
\end{array}\right)
$$

第 2 回路実測值

$$
\mathrm{Ym}_{3}=\left(\begin{array}{c}
0.000000040739715+0.000003666704086 \mathrm{j} \\
-0.00000000676949+0.000004237068901 \mathrm{j} \\
-0.000000052551798+0.000004927006035 \mathrm{j}
\end{array}\right)
$$

理想計測との比較誤差率 ( $\rightarrow$ は，行列要素間の演算 $)$

$$
\overrightarrow{\left(\frac{|\mathrm{Ym} 13-\mathrm{Ym} 1|}{|\mathrm{Ym} 1|}\right)}=\left(\begin{array}{l}
0.000000367883443 \\
0.000000907319624 \\
0.000005808107175
\end{array}\right)
$$

(5) 相別インピーダンス $[\Omega / \mathrm{km}]$

自回線インピーダンス実測值 (表示は小数点以下 7 桁まで) $\mathrm{Z}_{33}=\left(\begin{array}{ccc}0.0443069+0.477047 \mathrm{j} & 0.0408303+0.2387138 \mathrm{j} & 0.0417229+0.1939639 \mathrm{j} \\ 0.0408303+0.2387138 \mathrm{j} & 0.0460736+0.4745211 \mathrm{j} & 0.042677+0.2361722 \mathrm{j} \\ 0.0417229+0.1939639 \mathrm{j} & 0.042677+0.2361722 \mathrm{j} & 0.0480088+0.4719629 \mathrm{j}\end{array}\right)$ 理想計測との比較誤差率 ( $\rightarrow$ は, 行列要素間の演算)

$$
\begin{aligned}
& \overrightarrow{\left(\frac{|\mathrm{z} 033-\mathrm{z} 0|}{|\mathrm{z} 0|}\right)} \\
& =\left(\begin{array}{llc}
0.000000000020006 & 0.000000000217379 & 0.000000000189126 \\
0.000000000494803 & 0.000000000026055 & 0.000000000514748 \\
0.000000000229629 & 0.000000000277228 & 0.00000000004269
\end{array}\right)
\end{aligned}
$$

(6) 回線間相互インピーダンス実測值 (表示:下7桁まで) $\mathrm{Z}_{33}=\left(\begin{array}{lll}0.0399172+0.2092541 \mathrm{j} & 0.0407716+0.1972796 \mathrm{j} & 0.0416591+0.1771766 \mathrm{j} \\ 0.0407716+0.1972796 \mathrm{j} & 0.0416691+0.2047595 \mathrm{j} & 0.0426016+0.1932907 \mathrm{j} \\ 0.0416591+0.1771766 \mathrm{j} & 0.0426016+0.1932907 \mathrm{j} & 0.0435856+0.2002516 \mathrm{j}\end{array}\right)$ 理想計測との比較誤差率 ( $\rightarrow$ は，行列要素間の演算 $)$

$$
\overrightarrow{\left(\frac{|z 33-z|}{|z|}\right)}
$$

$$
=\left(\begin{array}{lll}
0.000004441631764 & 0.000011490118784 & 0.000002446571909 \\
0.000000584887653 & 0.000007793012546 & 0.000010598923513 \\
0.000006719539117 & 0.000025037767684 & 0.000012402787427
\end{array}\right)
$$

(7) 相別アドミタンス $[\mu \mathrm{S} / \mathrm{km}]$

自回線アドミタンス実測值（表示：下 7 桁まで）

$\mathrm{Y}_{33}=\left(\begin{array}{llc}0.0003671+3.9156161 \mathrm{j} & 0.0001338-0.8657872 \mathrm{j} & 0.0002391-0.2644152 \mathrm{j} \\ 0.0001337-0.8657875 \mathrm{j} & 0.0002393+3.9661896 \mathrm{j} & 0.0001242-0.8718378 \mathrm{j} \\ 0.0002391-0.2644151 \mathrm{j} & 0.0001242-0.8718379 \mathrm{j} & 0.00035+3.8372032 \mathrm{j}\end{array}\right)$ 理想計測との比較誤差率 ( $\rightarrow$ は, 行列要素間の演算)

$$
\begin{aligned}
& \overrightarrow{\left(\frac{|\mathrm{Y} 33-\mathrm{Y}|}{|\mathrm{Y}|}\right)} \\
& =\left(\begin{array}{lll}
0.000006021440799 & 0.000057496514903 & 0.00007483930277 \\
0.000002898687116 & 0.000006471333308 & 0.000037182602919 \\
0.000112879516667 & 0.000099940551584 & 0.000012098613149
\end{array}\right)
\end{aligned}
$$

(8) 回線間相互アドミタンス実測值（表示：下 7 桁まで） $\mathrm{y}_{33}=\left(\begin{array}{ccc}0.0002465-0.4548218 \mathrm{j} & 0.0001586-0.2762932 \mathrm{j} & 0.0002442-0.130588 \mathrm{j} \\ 0.0001587-0.276293 \mathrm{j} & 0.0000965-0.3519316 \mathrm{j} & 0.0001527-0.2575783 \mathrm{j} \\ 0.0002442-0.1305882 \mathrm{j} & 0.0001527-0.2575783 \mathrm{j} & 0.0002213-0.3948788 \mathrm{j}\end{array}\right)$ 理想計測との比較誤差率 ( $\rightarrow$ は，行列要素間の演算 $)$

$$
\begin{aligned}
& \overrightarrow{\left(\frac{|\mathrm{y} 33-\mathrm{y}|}{|\mathrm{y}|}\right)} \\
& =\left(\begin{array}{llc}
0.000051835088146 & 0.000180209559772 & 0.000151503587962 \\
0.000009088883783 & 0.000072925829788 & 0.000125879714412 \\
0.000228637184653 & 0.000338129671877 & 0.0001175773409
\end{array}\right)
\end{aligned}
$$


以上の検証結果から理論解析計算上の誤差は, 系統故障 6 ケースの条件の良い収集が得られれば，実用上無視でき るレベルにあると考えられる。今回の6ケースの故障条件 では，第 1 回路の線路定数誤差が無視できるレベルにある が，第 2 回路路定数は，第 1 回路に比較し 5 桁程度誤差が 大きくなっている。この理由は, 送電線 1 号線 2 号線を三 相ともループ状態にある送電線外部地絡故障が 2 ケース含 まれているためと見られる。

\section{5. まとめと今後の展開}

以上の検討結果，自動オシログラフを活用した送電線周 りの系統故障時デー夕記録により，送電線路定数を実測で きると考えられる。

現在，関係電力会社のご支援により，ほぼ実測可能な系 統故障条件のデー夕記録に基づく線路定数実測の準備を開 始するほか, さらに実測可能なデー夕検索を推進している。 実測に当たっては，系統中性点接地点間を通過する大地 帰路電流の乱れの少ない 1 回線停止中潮流や, 多相再閉路 遮断中の電圧電流データを優先活用するなど, 故障データ を精査の上, VT, CT 等の誤差補正も含めた送電線路定数 の実測精度向上を実践する。また，限られたデー夕条件に おける定数計算上の諸対策についても詳細な検討を進める。 得られた実測值については, 結果の背景にある系統条件 や故障条件を勘案しつつ, 従来使用の各種線路定数計算值
との対比・詳細分析を進める。

(平成 21 年 9 月 4 日受付, 平成 21 年 11 月 8 日再受付)

\section{文献}

(1) S. Hayashi: SURGES ON TRANSMISSION SYSTEMS, pp.15-29, DenkiShoin, Inc. (1955) (in Japanese)

林 重憲: SURGES ON TRANSMISSION SYSTEMS, pp.15-29, 電氣 書院 (1955)

(2) Y. Sekine and A. Ametani: Distributed constant circuit theory, pp.1-128, Corona Inc (1989) (in Japanese)

関根泰次·雨谷昭弘：分布定数回路論, pp.1-128, コロナ社 (1989)

(3) S. Urano, T. Yamada, Y. Ooura, Y. Yamaguchi, and T. Makimura: "Development of High Accuracy Impedance Type Fault Locator System", IEEJ Trans. PE, Vol.128, No.12, pp.1490-1496 (2008-12) (in Japanese) 浦野昌一・山田剛史・大浦好文・山口保孝・牧村達也:「高精度インピー ダンス型故障点標定システムの開発」, 電学論 B, 128, 12, pp.1490-1496 (2008-12)

大 浦 好 文 (正員) 1935 年 1 月 6 日生。1954 年 3 月福島工

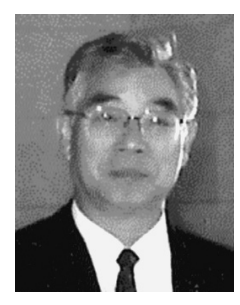
業高等学校卒業。現在 (株) 近計システム監査役。 1962 年電験第 1 種。1 992 年工学博士 (東京大学)。 1954 年 4 月東京電力 (株) 入社。系統運用部にて 系統保護制御システム・安定化技術部門を担務, 同部部長。2000 年退職。総合研修センター講師。 1987 年電気学会論文賞, 1989 年電気学会進歩賞, 1992 年 IEEE/PES’ Prize Paper Award，1994 年電 気学会業績賞受賞。 